\title{
Sentiment Traders \& IPO Initial Returns: The Indian Evidence
}

\section{DOI:}

10.1016/j.jcorpfin.2015.10.007

\section{Document Version}

Accepted author manuscript

Link to publication record in Manchester Research Explorer

\section{Citation for published version (APA):}

Clarke, J., Khurshed, A., Pande, A., \& Singh, A. (2016). Sentiment Traders \& IPO Initial Returns: The Indian Evidence. Journal of Corporate Finance, 37, 24-37. https://doi.org/10.1016/j.jcorpfin.2015.10.007

\section{Published in:}

Journal of Corporate Finance

\section{Citing this paper}

Please note that where the full-text provided on Manchester Research Explorer is the Author Accepted Manuscript or Proof version this may differ from the final Published version. If citing, it is advised that you check and use the publisher's definitive version.

\section{General rights}

Copyright and moral rights for the publications made accessible in the Research Explorer are retained by the authors and/or other copyright owners and it is a condition of accessing publications that users recognise and abide by the legal requirements associated with these rights.

\section{Takedown policy}

If you believe that this document breaches copyright please refer to the University of Manchester's Takedown Procedures [http://man.ac.uk/04Y6Bo] or contact uml.scholarlycommunications@manchester.ac.uk providing relevant details, so we can investigate your claim.

\section{OPEN ACCESS}




\title{
Sentiment Traders \& IPO Initial Returns: The Indian Evidence
}

\author{
Jonathan Clarke \\ College of Management \\ Georgia Institute of Technology \\ (jonathan.clarke@mgmt.gatech.edu) \\ Arif Khurshed \\ Manchester Business School \\ University of Manchester \\ (arif.khurshed@mbs.ac.uk) \\ Alok Pande \\ Ministry of Finance \\ Government of India \\ (alokpiimb@gmail.com) \\ Ajai K. Singh \\ College of Business Administration \\ University of Central Florida \\ (aks@ucf.edu)
}

This version: September 15, 2015

\begin{abstract}
We use India's unique regulatory design to test sentiment-based models of IPO initial returns. Using a sample of 362 Indian offerings from 2003-2014, we find that the traditional measure of IPO underpricing averages $23 \%$. We decompose the traditional underpricing measure into two components: one related to voluntary underpricing by the underwriter and the other component related to the IPO's first-day trading activity. We find minimal levels of voluntary underpricing. However, initial returns on the first day average $14 \%$ and are primarily driven by the unmet demand of non-institutional investor groups. Overall, our results support sentiment-based models of IPO initial returns.
\end{abstract}

JEL Classification: G11, G15, G18

Key words: IPOs, winner's curse, voluntary underpricing, initial returns, sentiment traders.

The authors thank an anonymous referee, Jeffry Netter (the editor), Michael Brennan, Matt Billett, Amit Bubna, Rick Carter, Laurie Krigman, Jay Ritter, Paul Schultz, Ann Sherman, Norman Strong, Yiming Qian and Anand Vijh for helpful comments. We also thank seminar participants at the U.S. Securities and Exchange Commission (SEC), Cambridge University, Case Western Reserve University, Iowa State University, Lehigh University, Louisiana State University, Manchester Business School, London Business School, University of Central Florida, University of Iowa, University of Notre Dame, University of South Florida, Workshop on IPOs 2010 (University of Bergamo), European Financial Association Meetings (Bergen 2009) and the Conference on Securities Markets (NISM, Mumbai 2008) for helpful comments. Any errors are our own. Pande wishes to acknowledge the financial support received from the Marie Curie Fellowship at Manchester Business School. Singh is grateful for financial support from the Bolton-Perella Chair during his tenure at Lehigh University, and from the SunTrust Chair in his current position.

Corresponding author: Ajai K. Singh, Department of Finance, CBA, University of Central Florida, Orlando, FL 32816-1400. Tel: 407-823-0761, Fax: 407-823-6676. 


\title{
Sentiment Traders and IPO Initial Returns: The Indian Evidence
}

\begin{abstract}
We use India's unique regulatory design to test sentiment-based models of IPO initial returns. Using a sample of 362 Indian offerings from 2003-2014, we find that the traditional measure of IPO underpricing averages $23 \%$. We decompose the traditional underpricing measure into two components: one related to voluntary underpricing by the underwriter and the other component related to the IPO's first-day trading activity. We find minimal levels of voluntary underpricing. However, initial returns on the first day average $14 \%$ and are primarily driven by the unmet demand of non-institutional investor groups. Overall, our results support sentiment-based models of IPO initial returns.
\end{abstract}

JEL Classification: G11, G15, G18

Key words: IPOs, winner's curse, voluntary underpricing, initial returns, sentiment traders. 


\section{Sentiment Traders and IPO Initial Returns: The Indian Evidence}

The positive first-day IPO returns have generally been labeled "underpricing" and the nature of this phenomenon has been documented extensively in capital markets across several countries. ${ }^{1}$ These findings have long intrigued financial economists because positive initial returns represent money handed over voluntarily by issuers. Early explanations model first-day IPO returns as "deliberate" or "voluntary" underpricing of shares issued in an asymmetric-information framework. However, Derrien (2005) and Ljungqvist, Nanda and Singh (2006) argue that positive initial returns do not represent money-left-on-the-table voluntarily. Instead, these models suggest that retailinvestors' sentiment drives an IPO's first-day returns. In this paper, we use the regulatory set-up and design of Indian offerings to directly evaluate the empirical predictions of sentiment-based models of IPO initial returns.

Traditional underpricing is typically measured from the IPO offer price to the newly listed stock's closing price on its first day of trading. However, this definition makes it difficult to separate and assess (1) the voluntary underpricing, i.e. estimate where the underwriter may have planned to price the IPO in the pre-listing period relative to its intrinsic value, and (2) the extent to which the first trading day's closing price is driven by investor sentiment and demand in the post-listing IPO aftermarket. The Indian process permits us to dissect IPO returns and to examine separately the money-left-on-the-table voluntarily in the pre-listing period and to distinguish it from the market driven post-listing initial returns.

Using a sample of 362 bookbuilt offers from 2003 to 2014, we find that the traditional measure of IPO underpricing averages $23 \%$. We decompose the traditional underpricing measure into two components: (1) voluntary underpricing, set by the underwriter in the pre-listing period and

\footnotetext{
${ }^{1}$ See, among others, Welch (1992), Loughran, Ritter and Rydqvist (1994), Ritter (1998), Ritter and Welch (2002), Ljungqvist and Wilhelm (2002). Loughran and Ritter (2002) provide an explanation consistent with voluntary underpricing of why issuers do not get upset about leaving money on the table.
} 
(2) the initial returns, determined using the IPO's market-driven closing price on its first day of trading. Our measure of voluntary underpricing in the pre-listing period averages $8.25 \%$. On the other hand, we find that the post-listing IPO initial returns average $14 \%$. Thus, we find that the magnitude of voluntary underpricing is significantly smaller relative to the IPO initial return.

Löffler, Panther and Theissen (2005) and Ljungqvist, Cornelli and Goldreich (2006) examine the pre-listing trades in IPO stocks in the European "grey markets". ${ }^{2}$ Löffler et al. (2005) report that the grey market (pre-IPO) price is an unbiased estimate of the stock's post-listing price once it starts trading on the exchange. Ljungqvist et al. (2006) also find that the high grey market prices (indicating over-optimism) are indeed a good predictor of first-day, post-listing IPO stock price. ${ }^{3}$ These papers conclude that the pre-IPO trading price in the grey market is highly informative. Their findings indicate that if the grey market price is used as the basis, the IPO initial return is small and that the variance of IPO underpricing is explained largely by the pre-listing grey market returns. Based on their evidence, we can conclude that the pre-IPO market traders primarily determine the European IPO initial returns. However, the identity of traders in the European pre-IPO grey markets is not easily distinguishable. ${ }^{4}$

In contrast, Indian regulation requires that subscribers' application information, by investor type (institutional and non-institutional), be publicly available online during the IPO bookbuilding period. Further, not only does the Indian IPO data identify the specific demand by each investor type in the pre-listing period but also the number of shares actually allocated to them. Accordingly, for Indian IPOs, we are able to directly observe the level of shares subscribed for, and as stated

\footnotetext{
${ }^{2}$ European grey market trades are perfectly legal forward trades and the grey market stock prices are widely disseminated over Reuters, Bloomberg and other news outlets.

${ }^{3}$ Ljungqvist, Cornelli and Goldreich (2006) report that the low grey market prices, which indicate excessive pessimism, are not as informative. It must be noted that underwriters' price stabilization activity for weak demand IPOs affects the aftermarket prices for such IPOs.

${ }^{4}$ The European grey market is generally presumed to be dominated by retail investors but it is open to institutional investors and they also participate in it. Loffler et al. (2005) assert that suppliers of the stock in the pre-IPO markets are not retail investors because they cannot easily borrow and short sell shares of any stock, and not just specifically IPO stocks.
} 
above, the unmet demand of each investor group, both institutional and non-institutional. Given that the Indian data includes the unmet demand of each investor group, it permits us to examine its impact on the IPO's initial return in the post-listing aftermarket. ${ }^{5}$

We find that the unmet demand of the non-institutional investors drives the IPO stock's initial return on its first day of trading. Specifically, IPO initial returns are significantly higher for offers with greater demand from non-institutional investors. For example, IPOs in the bottom quartile of the retail demand have initial returns of $-10.49 \%$, while issues in the top quartile of retail demand have initial returns of $52.64 \%$. Interestingly, the unmet demand of institutional investors is not related to the IPO initial return even though they have large unfilled positions. These results hold in a multivariate regression framework where we control for firm age, issue size, and voluntary underpricing, among other factors.

Many of the asymmetric information based models of IPO initial returns employ the stylized fact that investment banks, in the US and in many other parts of the world, retain discretionary allocation powers. Accordingly, investment banks are free to allocate IPO shares to their chosen buy-side clients, usually on some quid pro quo basis. The Indian setting provides a unique opportunity to examine the impact of this attribute on IPO initial returns because, since November 2005, Indian regulators have stripped investment banks of their power to allocate IPO shares at their discretion. We examine the impact of this important change and find that IPO initial returns before and after the regulatory shift are not statistically different. Our primary result that the unmet demand of uninformed investors plays a significant role in determining the post-listing initial returns holds both before and after November 2005.

\footnotetext{
${ }^{5}$ The unmet demand refers to the difference between the number of shares subscribed for and the number of shares allocated to each investor group. This data is publicly available for Indian IPOs. The voluntary underpricing and the IPO initial returns are defined and discussed in detail in Section 2.3.
} 
The transparency of the Indian IPO process and the result that the November 2005 regulatory change is a non-event, indicate that IPO initial returns are not affected by the removal of underwriters' discretionary allocation power. These findings complement and expand on those in Löffler et al. (2005) and Ljungqvist et al. (2006). We conclude that the regulatory framework and the transparency of the book-building process in India alleviate the winner's curse problem and reduce the need for voluntary underpricing. Overall, our evidence is generally supportive of the investorsentiment based models of IPO underpricing.

Finally, our research highlights a central point made by Fan, Wei and Xu (2011) that institutional differences between emerging and developed markets can be used to gain significant insight into a broad array of corporate finance topics. Their insight is particularly apt for this study. In our case, the transparency of the Indian IPO process allows for more direct tests of sentiment based models of IPO underpricing than would be possible with U.S. data or data from developed nations.

The rest of the study is organized as follows. A detailed discussion of bookbuilding and other regulations governing the IPO process in India is given in Section 2. We develop the hypotheses in Section 3. We discuss data and methods in Section 4. The results are covered in Section 5. Finally, section 6 concludes.

\section{2: Bookbuilding in India}

\section{1: The institutional setup}

Until the early 1990s the Indian primary issue market was regulated by the Controller of Capital Issues (CCI), a government regulator, who also determined the price at which IPO firms offered their shares to the market. In 1992 the Capital Issues (Control) Act was abolished bringing an end to the control on pricing of new issues and the Securities and Exchange Board of India (SEBI) took over as the new market regulator. Even though SEBI introduced bookbuilding guidelines for 
primary markets as early as 1995, almost no bookbuilding activity was seen in the Indian IPO markets until 1999-2000. Ljungqvist, Jenkins and Wilhelm (2003) exclude the Indian capital markets in their cross-country analysis of IPO bookbuilding activity for this reason.

Unlike the US where bookbuilding has been the preferred method of IPO price discovery for more than two decades, the Indian IPO market did not use this method until 1999. However, by 2006, more than $80 \%$ of Indian IPOs priced their shares using the bookbuilding mechanism. In Appendix A, we further discuss the differences between the U.S. and Indian bookbuilding processes.

\section{2: The dynamics of the bookbuilding process in India}

Figure 1 illustrates the various stages of the IPO process with the help of an observation in our sample. At the first stage, a firm conducting an IPO selects its investment banker, formally known as the Book Running Lead Manager. The lead banker (also known as the bookrunner) files a Draft Red Herring prospectus with the regulator. ${ }^{6}$ At this stage, a price band is not disclosed. The bookrunner carries out the preliminary pricing of the firm and circulates it in the form of a report amongst its favored institutional clients. Then the bookrunner and the firm go on a road show.

According to the Indian regulatory setup, investors are divided into three categories and the allocation tranches of these categories are pre-defined. Institutional investors (known as Qualified Institutional Buyers or QIBs) are allocated no more than $50 \%$ of the shares offered. Noninstitutional investors (NIIs), defined as individuals investing more than Indian Rupee (INR) 100,000 in the issue, are allocated $15 \%$ of the offered shares. Retail investors, who can invest up to a maximum of INR 100,000 have to be allocated no less than $35 \%$ of the offered shares. We define the non-institutional investors as the joint sum of the Retail and the NIIs.

At the end of the road show the bookrunner uses the recently collected information to arrive at a price band and files a Red Herring prospectus with the regulator. The Red Herring prospectus

\footnotetext{
${ }^{6}$ In the rest of the manuscript, we use the term bookrunner, investment banker and underwriter interchangeably.
} 
contains the price band on which the book is built. ${ }^{7}$ On average, the bookbuilding process usually lasts for a period of 5 days (a minimum of 3 days and a maximum of 10 days is prescribed by regulation). Unlike in the U.S., the price band is seldom revised. ${ }^{8}$ Once the red-herring prospectus has been filed, the bookrunner forms a syndicate of brokers, financial service providers and banks to carry out the bookbuilding for the firm. The syndicate members have the right to accept bids from investors.

Regulation does not permit any special benefits be conferred on those who subscribe early in the bookbuilding process. Further, all investor types, including QIBs, have to place their bids through the syndicate. The bids placed by all categories of investors can be modified during the bookbuilding period. Non-institutional investors have to put in the full amount mentioned in their bid applications, whereas QIBs are permitted to apply with only $10 \%$ of the application money. ${ }^{9}$

The bids are electronically entered by the syndicate members and the book is updated at the Bombay Stock Exchange (BSE)/National Stock Exchange (NSE) websites. By regulation, the books on the BSE/NSE are updated every half-hour. At the end of each bookbuilding day the stock exchange websites show the cumulative bids at their respective prices. The web sites also show how many shares against each of the investor-categories have been applied for and the percentage of the issue that has been subscribed to. Such an arrangement stands in contrast to the bookbuilding exercise in the US and the UK markets, where the information about the book is rarely available; and if any, it becomes available expost.

\footnotetext{
7 The price band and the measures of voluntary underpricing and IPO initial returns are discussed in detail in Section 2.3

${ }^{8}$ Of the 362 observations in our sample, there are only 6 observations where the price band was revised downwards. These 6 observations are included among the Atypical offers, defined in the following section. There are no observations where the price band was revised upwards.

${ }^{9}$ Retail investors are also allowed to make "cut off" bids instead of indicating a price within the band (price bid). Cut off bids allow retail investors to participate in the allocation process at whatever "cut off" price is determined by the book. For instance, if a retail investor makes a price bid at INR 220 and the price determined by bookbuilding is INR 230, then such a retail investor would not get any shares allocated to her. On the other hand, a cut off bid would consider the retail investors' application at a price of INR 230 for allocation purposes.
} 
After the book has been built, the issuing firm, in consultation with the bookrunner, decides an offer price for the IPO shares. This is the third stage of the process. If the issue has been oversubscribed by investors in any category, allocation is made among the investors in that specific class by means of a lottery. If the issue has been under-subscribed in any investor category then the firm can reallocate the unsubscribed shares to any over-subscribed category as per the disclosures made on this subject in the prospectus.

The basis of allocation document is made public by the Registrar of the IPO at this stage. Investors with share allotments receive the shares in their account whereas unsuccessful subscribers are refunded their application money. The procedure has to be complete within 15 days of the closure of the book; else a $15 \%$ interest has to be paid to investors.

The final prospectus containing the offer price is filed with the Registrar of Companies. The listing of the IPO is the fourth and final stage of the process. The IPO is listed 21 days after the determination of the offer price to ensure that the application money refunds and settlements have been cleared before the first day's trade.

\section{3: The Price Band, Voluntary underpricing and IPO Initial Return}

As discussed in the previous section, the price band is first disclosed at the end of the roadshow when the Red Herring Prospectus is filed. The price band gives a minimum and a maximum price and thus, a range within which the offer is priced. The price band is defined as [L, MAXA] where the bookrunner sets the lower end of the range (denoted as L) at private placement levels immediately preceding the IPO. ${ }^{10}$ By regulation, the maximum permissible price (henceforth MAXP) of the price range cannot exceed $120 \%$ of $\mathrm{L}$. Thus MAXP is a function of L; once L is determined it automatically defines MAXP. For example, if $\mathrm{L}$ is set at INR 200, it automatically defines MAXP as

\footnotetext{
${ }^{10}$ It is customary to place shares privately with business associates and some institutional investors before the IPO.
} 
INR 240 (L*1.2). Approximately 90\% of firms set the actual upper end of the price band MAXA below MAXP. The terms are best explained with an example below.

We continue using the sample observation in Figure 1 as an example (see Section 2.2), to specify our definitions of the voluntary underpricing by the underwriter and the initial returns in the post-listing aftermarket. Simplex Projects filed its 3,000,000 shares IPO on June 28, 2007. Upon completion of the road show, which is conducted without a price band, Simplex Projects set its bookbuilding price range [L, MAXA] at INR [170 - 185] on July 10, 2007. As discussed above, once the lower end of the price range L is set at INR 170, MAXP is defined automatically at INR 204 $(120 \%$ of L, i.e. $1.2 * 170$ or 204$)$. MAXP is, by regulation, the maximum permissible upper end of the price band. Although the upper end of the range could have been set at INR 204, the underwriter chose to keep MAXA, the actual upper end of the price band, at INR 185. In this example, L is 170, MAXA is 185 and MAXP is 204. The four-day long bookbuilding period ended on July 13, 2007. The Simplex Projects issue was heavily oversubscribed (86 times). Upon completion of the bookbuilding process, the underwriter in consultation with the issuer set the offer price (OP) at INR 185, equal to MAXA.

Our measure of expected voluntary underpricing, E(VUP), is defined as (MAXPMAXA)/MAXP; which in this example equals $(204-185) / 204$ or $9.31 \%$. Once the offer price is set at INR 185, our actual underpricing measure VUP, defined as (MAXP - OP)/MAXP can be computed. ${ }^{11}$ Since the offer price OP has to be set in the interval [L, MAXA], it has to be less than or equal to MAXA. Therefore, E(VUP) is the minimum level of voluntary underpricing and it measures the extent to which the firm voluntarily restrains itself from setting MAXA at the maximum permissible level MAXP. In this instance, as is typically the case, the expected VUP equals

\footnotetext{
${ }^{11}$ The expected level of the voluntary underpricing E(VUP) can be computed when the bookbuilding period starts and the price range is declared but before the offer price OP is decided upon. The actual VUP can be determined post-bookbuilding only after OP is finalized. The actual VUP defined as (MAXP - OP)/MAXP is different from the expected only if the offer price OP is set below MAXA.
} 
the actual level of voluntary underpricing; the actual voluntary underpricing VUP equals E(VUP) for approximately $74 \%$ of our sample. In other words, for 267 observations in our sample of 362, OP is set equal to MAXA; only 95 (or $26 \%$ of the sample IPOs) set their OP below MAXA. We refer to these 95 observations as "Atypical" IPOs. For Atypical observations, the Actual VUP is greater than expected.

The Actual VUP is the closest we can get to a measure of the amount of money intentionally left on the table. The firm chooses both $\mathrm{L}$ and MAXA when it sets the price range. It could have set L equal to MAXA/1.2. Alternately it could have set MAXA equal to $1.2 *$ L. In either case, MAXA would be equal to MAXP and the expected VUP would then be equal to zero. The fact that MAXA is voluntarily set below MAXP in about $90 \%$ of our sample observations implies that IPO firms and their lead banker choose to set $\mathrm{E}(\mathrm{VUP})>0$, arguably as an inducement to potential buyers. We consider the Actual VUP to be a measure of voluntary underpricing set by the issuing firm and its investment banker before the IPO begins trading.

The closing price (CP) of Simplex Projects on August 3, 2007, the first day of its listing, was INR 273.70. In the post-listing aftermarket, the first-day returns are traditionally measured as the difference between the first trading day's closing price $(\mathrm{CP})$ and the offer price $(\mathrm{OP})$ as a proportion of the offer price. However, in the Indian context, since we expect the market to know that the maximum price at the upper end of the band could have been MAXP, this definition can be modified. We define and measure the Initial Return (IR) as the difference between the first day closing price (CP) and MAXP, as a proportion of MAXP. Accordingly, in this example, the initial return IR is (CP - MAXP)/MAXP or $(273.70-204) / 204$ or $34.17 \%$. The traditional measure of underpricing would have been (CP - OP)/OP or $(273.70-185) / 185$ or $47.95 \%$. 
Note that (VUP + IR) represents an approximate dissection of the traditional measure of underpricing into VUP (measured pre-listing) and IR (measured post-listing), the difference from the traditional measure only being in the denominator, where we use MAXP instead of OP.

\section{3: Related literature and testable hypotheses:}

Aggarwal, Prabhala, and Puri (2002) examine a sample of IPOs between 1997 and 1998 and find a positive relation between institutional allocation and first day IPO returns. The authors argue that institutions receive a greater share of IPOs with stronger pre-market demand, which is consistent with the book-building models of Rock (1986) and Benveniste and Spindt (1989). In Benveniste and Spindt (1989), for example, discretionary powers to allocate IPO shares allow bookrunning investment bankers to extract information from buy-side clients. Buy-side investors have an incentive to reveal their private assessment (information) of the stock's value. As a quid pro quo they are rewarded with allocations of high-demand IPO shares, which are priced by the bookrunner below the reservation prices revealed by investors. That is, there is an inbuilt voluntary "underpricing" and the offer price is adjusted only partially by the bookrunner to incentivize buyside investors to reveal their true assessment of the IPO firm. ${ }^{12}$

The Benveniste and Spindt (1989) quid pro quo model of underpriced shares in exchange for private information and Rock's (1986) winners' curse model have been questioned in the context of European IPO evidence. Löffler et al. (2005) find that the grey market prices are related to the IPO's closing price on the first day of trading and conclude that, for the most part, the price discovery has already occurred in the grey market. Therefore, if the grey market price is used as the basis, the IPO initial return is small. Löffler et al. (2005) conclude that the variance of IPO underpricing is explained largely by the pre-listing grey market returns.

\footnotetext{
${ }^{12}$ Hanley (1993) and Loughran and Ritter (2002) empirically validate the partial-adjustment phenomenon, modelled by Benveniste and Spindt (1989).
} 
In the case of Indian IPOs, we can observe voluntary pre-offer underpricing and the marketdriven post-listing initial returns. In this setting, it is not obvious whether the voluntary pre-IPO underpricing (which is measured by the location of the offer price relative to MAXP) has any relation to the IPO initial returns observed in the post-listing aftermarket. ${ }^{13}$ We posit that the investment banker signals her confidence by setting MAXA higher and closer to MAXP. She confirms this signal of confidence by setting OP equal to MAXA. In contrast, if she sets the offer price below MAXA, it signals weakness. These factors lead to our first hypothesis.

H1: The initial return IR observed in the post-listing IPO aftermarket is related to the voluntary underpricing (i.e. the higher the IPO offerprice set relative to MAXP, greater is the initial return IR).

Purnanandam and Swaminathan (2004), Derrien (2005), Ljungqvist et al. (2006) argue that the offer price is set above the intrinsic value of IPO shares being offered. Derrien (2005) and Ljungqvist et al. (2006) argue that the IPO market is characterized by two types of investors, namely sentiment (or noise) traders and regular "rational" investors, who are arguably the institutional investors. In both models regular investors benefit from flipping overvalued shares to sentiment traders who overpay, and the issuer and rational investors benefit from the sale of the "overpriced" IPO shares. These models are similar to the Benveniste and Spindt (1989) information extraction model with a difference. In Benveniste and Spindt (1989) IPO underpricing is the inducement to institutional investors to reveal their private valuation of the IPO stock. However, in Derrien (2005) and Ljungqvist et al. (2006) the rent is paid by sentiment traders who overpay because their reservation prices exceed the intrinsic value of the IPO shares.

Both Derrien (2005) and Ljungqvist et al. (2006) predict that the IPO price and the level of initial returns increase with the intensity of sentiment traders' demand at the time of the offering. In the context of Indian IPOs, unlike the European offerings, we are able to observe the precise level

\footnotetext{
${ }^{13}$ Note that we measure the IPO initial return as the difference between the first day's closing market price and MAXP, scaled by MAXP.
} 
of unmet demand of each type of investor, institutional and non- institutional. Accordingly, we can check whether the demand (or the unmet demand) of any specific investor group contributes more to the IPO initial returns. This fact permits a direct test of the Derrien (2005) and Ljungqvist et al. (2006) models and leads to our next hypothesis:

H2: The initial return observed in the post-listing IPO aftermarket is positively related to the unmet demand of noninstitutional investors.

Finally, the regulatory shift in November 2005 stripped investment banks of their discretionary allocation powers. If indeed the discretionary allocations help in the price discovery process, as suggested by Benveniste and Spindt (1989) in their information-extraction quid pro quo model, we should find higher initial returns pursuant to this regulatory shift. This leads to our final hypothesis:

H3: The initial return observed in IPO aftermarket should be higher following the post-November 2005 regulatory change.

\section{4: Sample construction \& description}

\section{1: Sample Construction}

Our primary sample consists of 362 Indian IPOs between 2003 and 2014 . We begin the sample in 2003, because a new regulation was introduced whereby the cap of the bookbuilding band could not exceed $120 \%$ of the floor price. Hence, the bookbuilding band was regulated to be between $(\mathrm{X}, 1.2 \mathrm{X})$ where " $\mathrm{X}$ " is the lower end of the band. Our sample captures the majority of bookbuilt IPOs in India. ${ }^{14}$

The first source for collecting the prospectuses for the sample of 362 IPOs is SEBI's (Securities and Exchange Board of India) website, which provides the Draft Red Herring Prospectus

\footnotetext{
${ }^{14}$ While bookbuilding started in 1999, only 27 IPOs occurred between 1999 and 2002.
} 
(DRHP), the Red Herring Prospectus (RHP), and the Prospectus. If the final prospectus is not available on SEBI's website, we collect the Red Herring prospectus and complement this by searching on Thomson One Banker. We obtained prospectuses for 297 of our 362 IPOs from SEBI's website. In addition we obtained prospectuses of 11 other firms from Thomson One Banker. For 54 firms, we obtained the final prospectuses/Red Herring prospectus from Prime Database, a private agency which tracks Indian IPOs. Information on the year of incorporation of the firm, issue size, number of shares offered, name of the book-running investment banker, the price band as well as the final price has been collected from the final prospectus.

The age of the firm is calculated as the difference between the year the firm goes public and its year of incorporation. We take the earliest year of incorporation even if the firm was incorporated in a name other than the one in which it went public. We collect the closing price on the day of listing from the National Stock Exchange (NSE) website. If the firm was listed on both the NSE and the Bombay Stock Exchange (BSE) we take the NSE closing price. Since there is a lag of almost 3 weeks between the closure of the book and the listing of the firm, we take into account market returns during this period using the S\&P CNX Nifty, an index composed of 50 firms listed on the NSE.

For allocations to the three investor categories, Retail, Non-Institutional Investors (or NIIs) and QIBs, we rely on the Master Response Sheet published by Prime Database, which provides information on applications, allotments and subscription levels for each class of investor. We also cross-check a sample of this data with the details on the basis-of-allotment documents published by the various Registrars.

We also collect the day-by-day bookbuilding for the three classes of investors. To the best of our knowledge this data is publicly available for only the 287 IPOs between April 1, 2006 and December 31 ${ }^{\text {st }}$, 2014. For IPOs between 2006 and 2007, we collect the daily bookbuilding data 
from the live update of the IPOs on the NSE and BSE. Demand has been captured from the NSE website at 1900 hours on each day of the IPO bookbuilding. For the 2008-14 IPOs, we obtain daily demand data from www.chittorgarh.com, which is considered to be India's main IPO investment portal. These data give us information on the category-wise demand (subscription) for each day of the bookbuilding for QIBs, NIIs and Retail investors. The demand levels in these data are given by the subscription levels for each category of investor for each day. The subscription level is the ratio of the number of shares subscribed in a specific investor category to the number of shares on offer for that category. Therefore, a subscription level of 0.5 at the end of a day for the QIB category implies that $50 \%$ of shares reserved for QIBs were bid for subscription by them on that particular day. The data for these demand levels is cumulated on a daily basis.

\section{2: Sample descriptive statistics}

Table 1 gives a complete description of the variables used in this study. Table 2, Panels A and B provide the breakdown of our sample of 362 bookbuilt IPOs, by the year of issue and industry. Panel C presents statistics for traditional underpricing by year. We report descriptive statistics separately for Typical and Atypical IPOs. Panel A shows that of the 362 IPOs, 267 are classified as Typical. After 2003-2004, approximately 20\% to 30\% of IPOs each year are classified as Atypical. Table 2, Panel B shows that construction, personal goods, software, and media firms account for $33.7 \%$ of the sample. Panel $\mathrm{C}$ of Table 2 shows the variation in traditional underpricing over time in bookbuilt IPOs. Overall, traditional underpricing averages $22.79 \%$. This is similar to the $25.01 \%$ documented by Banerjee et al. (2011) for Indian IPOs between 2000 and 2006. From the year 2006 to 2013, traditional underpricing generally decreased. This trend reversed in 2014 when traditional underpricing increased to $39.35 \%$. Atypical IPOs have average traditional underpricing of $3.20 \%$ versus $29.76 \%$ for the Typical IPOs. The difference is significant at the $1 \%$ level. 
Table 3 provides descriptive statistics of the variables used in the study. We report descriptive statistics for the full sample and separately for Typical and Atypical offers. For the full sample, the amount raised (Issuesize) averages INR 44,845. Our definition of Initial Return (IR) is the excess of the Closing Price over the Maximum Permissible upper band price (MAXP). IR has a mean of $13.92 \%$ whereas that of the conventional measure of IPO underpricing is $22.79 \%$. The voluntary underpricing Actual VUP averages $8.25 \%$. As discussed before, the sum of the initial return IR and the post-book underpricing Actual VUP approximates the traditional measure of IPO underpricing. The average age of the Indian IPO firm is about 16 years at the time they go public, which is similar to US firms (Habib and Ljungqvist 2001). Firm age is missing for two observations. These two firms are excluded from regressions where age is a control variable.

Within the three categories of investors, the NII category shows the highest levels of oversubscription. On average, NIIs subscribe approximately 33 times their tranche of shares in the IPO. This could be driven by their smaller pre-determined tranche size. QIB and Retail subscriptions are generally lower than those of NII investors. On average, the offer price OP is INR 203.23, while the actual band maximum MAXA is INR 208.02. The maximum permissible band price MAXP is INR 222.77, averaging approximately INR 14.75 (7.1\%) above MAXA.

We also observe in Table 3 that Atypical offers tend to be larger, have lower initial returns and underpricing and less demand for the offering from Retail, NII, and QIB investors. Thus, weak investor demand is a characteristic of Atypical offers.

In Table 4, we examine the likelihood of an offer being Typical. The dependent variable takes the value of one if MAXA is equal to the offer price and zero otherwise. In the first specification, we find that higher subscription levels, from both retail (RET_sub) and institutional investors (QIB_sub) increase the likelihood of an offer being priced at MAXA. The second specification confirms that high demand from investors (QIB_sub and NonQIB_sub) drives the offer 
price OP towards MAXA. We also find that older firms are more likely to be typical, while larger offerings are less likely to be Typical. These findings are not obvious a priori because the institutional investor and the investment bank are not tied to each other through an information-extraction quid pro quo relation. It is also interesting to note that the strong demand from retail investors is also related to the choice of pricing the IPO at MAXA. Apparently a weakness in investor interest keeps the investment banker from pricing the offer higher and she sets OP below MAXA.

\section{5: Results}

\subsection{Univariate Analyses}

Table 5 provides the subscription pattern for the subsample of 287 IPOs between April 1, 2006 and December 31 ${ }^{\text {st }}$, 2014, where the day-by-day bookbuilding demand data is publicly available. Panel A analyzes the first day's bookbuilding demand for the three categories of investors grouped by Atypical and Typical IPOs. Median non-institutional subscriptions are paltry. Retail investors register very little demand on the first day of bookbuilding regardless of the type of the issue. The sample medians for NIIs and QIBs also show little demand on the first day.

Panel B of Table 5 reports the penultimate day of bookbuilding. By the penultimate day, QIBs oversubscribe all IPOs regardless of type. The mean oversubscription is 5.76 for Typical offers and 1.66 for Atypical offers. The median values also show oversubscription for the Typical offers. For Typical offers, the average non-institutional (NII and retail) mean subscriptions levels are greater than one. In contrast, Atypical offers have comparatively low levels of non-institutional demand on the penultimate day.

Panel C of Table 5 analyzes the last day of bookbuilding. For both Typical and Atypical offers, all categories of investors show oversubscription. The overall subscription level for the Atypical offers is significantly smaller than it is for the Typical offers. Both the institutional and the 
non-institutional demand is significantly lower for the Atypical offers. The main takeaway from Table 5 is that the subscription activity is open and public, which is not consistent with Rock's (1986) winners'-curse setting where uninformed investors are not aware of the IPOs that are in greater demand by the informed investors.

Table 6, reports the initial returns of the IPOs, by each quartile level of subscription, for each of the three categories of investors for the full sample of 362 IPOs. The initial returns are negative for the lowest levels of demand, and they are positively related with the increase in subscription levels. Table 6, Panel B provides the breakdown of the initial returns by the subscription level quartiles for the Typical offers. We find that IPO initial returns increase monotonically with the increase in subscription levels. This is true for both the institutional and the non-institutional subscription levels.

In Panel $\mathrm{C}$ of Table 6, we find that initial returns are generally much smaller for the Atypical offers. It appears that the market responds negatively to the investment banker not pricing the offer at MAXA. The facts that OP is set below MAXA for Atypical offers is indicative of weak demand and is viewed negatively by investors in the market upon its listing.

\section{2: Multivariate analyses}

In Table 7 we report results examining the determinants of the IPO initial returns IR. The regressions include controls for firm age, issue size, and the overall market return on the first day of trading. While we do not have data on all of the control variables identified in Butler, Keefe, and Kieschnick (2014), firm age, issue size, and the overall market return capture significant variation in the initial returns of Indian IPOs. Model 1 of Table 7 shows that the measure of voluntary underpricing, Actual VUP, is negatively related with the IR for the full sample of offerings. It is to be noted that VUP is zero when MAXA is set equal to MAXP. Thus our result indicates that the closer MAXA is set to MAXP, and the smaller Actual VUP is, the higher is the initial return. This finding is 
supportive of our first hypothesis. The market views it as the signal of the investment banker's confidence in being able to price the IPO closer to the maximum permissible level.

Model 1 of Table 7 also shows that IR is significantly driven by the subscription levels of non-institutional (NII and Retail) investors. Interestingly, despite the high QIB subscription levels, as seen in Table 5, the QIBs demand is not related to the IPO initial returns. This finding is supportive of our second hypothesis. The market return between the close of bookbuilding to the listing day also contributes significantly to the IPO initial return (IR).

In Table 7, Model 2, we examine the determinants of the Typical IPO initial returns. Our measure of the voluntary underpricing Actual VUP is significantly and negatively related to IR. As discussed above, the market responds positively to the offer price OP (and MAXA) being set closer to MAXP. The other important results remain the same as in Model 1 with the subscription levels of non-institutional investors and market returns retaining significant explanatory power.

Table 7, Model 3 examines the Atypical offers. Only the market return and Actual VUP explain the variability in the Atypical IPO initial returns. Subscription levels by QIB and non-QIB investors are not significantly related to initial returns. As noted before, these offers have very little interest from non-institutional investors.

It has generally been argued that the institutional investors represent smart money. Accordingly, in the rest of our analyses, we combine the numbers for the retail and NII to obtain a composite measure of the demand by non-institutional investors. This makes a clean distinction between the QIBs and NonQIBs and permits a direct comparison between the two. In Table 8, the combined (retail and NII) subscription level is denoted as NonQIB_sub. The results are virtually identical to those in Table 7 for all three models. In Model 2 of Table 8 we find that the greater the subscription levels of NonQIBs, the higher is the initial return IR for the Typical offers. As noted before, the NonQIBs show little appetite for Atypical offers and only Market_Return and Actual 
VUP are significant in Model 3 of Table 8. Also, as noted earlier in Table 7, the subscription level of the QIBs denoted as QIB_sub is unrelated to the IPO initial return in all three models of Table 8 as well.

It is possible that the actual subscription levels do not cleanly pick up the level of unmet demand from the non-institutional investors. Therefore, in the rest of our analyses, we use NonQIB_Unmet which is defined as the sum of the number of shares that are bid in excess of the number of shares allocated to the NII and retail investors, as a proportion of the number of shares offered in the IPO. Thus, NonQIB_Unmet is a measure of the demand in excess of the shares allocated to the non-institutional investors. The results are presented in Table 9. We find that the unmet demand of the non-institutional investors is strongly related to the IPO's initial return from its first day of listing. For the Typical offers, the NonQIB_Unmet, Market Return, and Actual VUP are significantly related to IR. The greater the demand from the non-institutional investors, higher is the IPO initial return. As in Tables $7 \& 8$, the closer OP is set to MAXP (i.e. smaller the voluntary underpricing Actual $(U P)$, higher is the initial return IR. The results are robust to the inclusion of the unmet demand of the institutional investors. Interestingly, the coefficient of the voluntary underpricing Actual VUP becomes marginally significant even for the Atypical offers, consistent with the argument that the higher the offer price the better the price reaction.

These findings are supportive of our first two hypotheses. The setting of the offer price relative to MAXP, the maximum permissible within the price band, is significantly related to the aftermarket IPO initial return (IR). Further, the unmet demand of the uninformed investors, who are arguably the sentiment traders of Derrien (2005) and Ljungqvist et al. (2006), is significantly related to the IPO initial return. In contrast, institutional investors (QIBs) do not appear to participate in the aftermarket buying activity. We consider these results to be generally consistent with the sentiment-trader explanation of Derrien (2005) and Ljungqvist et al. (2006). 


\section{4: IPO aftermarket: The removal of the investment banker's discretionary powers}

Underwriters' discretionary allocation power serves as the primary underpinning for many information-extraction based theoretical models that seek to explain IPO initial returns. The November 2005 regulatory shift in India stripped investment bankers of discretionary powers to make preferential allocation to their buy-side institutional clients. The change provides a unique opportunity to examine the impact of discretionary allocations on the IPO initial returns. In a recent paper, Bubna and Prabhala (2011) argue that this regulatory change has made the price discovery process noisier for Indian IPOs. In support of their argument, they find that the removal of the discretionary allocation powers in 2005 was followed by higher IPO initial returns. We re-examine this question using a larger sample in the post-2005 period.

The results of our analysis are presented in Table 10. We use the indicator variable Period which equals one for IPOs following the removal of the underwriters' powers in November 2005, and is set at zero otherwise. The variable Period is insignificant in all the models examined. We do not find any difference in the initial returns between the two regimes i.e. before and after the underwriters were stripped of their discretionary allocation powers. Interestingly, the interaction of the Period indicator variable and the unmet demand of non-institutional traders (NonQIB_Unmet) is significant, indicating that the unmet demand of the sentiment traders had a greater role to play in explaining the IPO initial returns in the post November 2005 period. As such, this evidence is not supportive of information extraction models to explain positive first day IPO initial returns.

It is also interesting that we are able to explain almost $50 \%$ of the variation in the initial return using information publicly available at the time of the IPOs' public listing. The finding is consistent with Bradley and Jordan (2002) who also document a similar result. Derrien (2005) argues that such evidence is not consistent with the idea that IPO initial returns are a cost borne to extract private information from buy-side institutional investors. 


\section{6: Conclusions}

Indian IPO data provides a unique opportunity to examine the efficacy of different models of IPO underpricing. The transparency of the process allows us to determine the level of demand from institutional and non-institutional buyers. Further, we are able to dissect the traditional measure of IPO underpricing into a pre-IPO, voluntary underpricing component and a post-IPO, marketdriven initial return component. We find that it is the unmet demand of the non-institutional investors that is the primary driver of IPO initial returns. Sophisticated investors (QIBs) seem content with their allocations and do not participate in the aftermarket buying activity.

We find that greater transparency helps in reducing the winner's curse for retail investors. However, this does not reduce IPO initial returns. IPO initial returns persist (but do not increase) even when investment bankers were stripped of their discretionary allocation power in November 2005. Further, we find that nearly $50 \%$ of the variability in IPO initial returns can be explained using publicly available information. Our results provide direct evidence, consistent with Löffler et al. (2005), Ljungqvist et al. (2006), Jenkinson and Jones (2009), that information extraction plays a small role in driving IPO initial returns, while the unmet demand of non-institutional investors is its key determinant. We consider these results to be supportive of the sentiment-based models of IPO initial returns developed by Derrien (2005) and Ljungqvist et al. (2006). 


\section{References}

Aggarwal, R., N.R. Prabhala, and M. Puri, (2002) Institutional Allocation in Initial Public Offerings: Empirical Evidence, Journal of Finance, Vol. 57(3), pp. 1421-1442.

Banerjee, S., L. Dai, and K. Shrestha, (2011) Cross country IPOs: What Explains Differences in Underpricing? Journal of Corporate Finance, Vol. 17, 1289-1305.

Benveniste, L.M. and P.A. Spindt, (1989) How Investment Banks Determine the Offer Price and Allocation of New Issues, Journal of Financial Economics, Vol. 24, pp. 343-361.

Bradley, D. and B.D. Jordan, (2002) Partial Adjustment to Public Information and IPO Underpricing, Journal of Financial and Quantitative Analysis, Vol. 37, pp. 595-616.

Bubna, A. and N.R. Prabhala, (2011) IPOs With and Without Allocation Discretion: Empirical Evidence, Journal of Financial Intermediation, 20 (4), pp. 530-561.

Butler, A., M. Keefe, and R. Kieschnick, (2014) Robust Determinants of IPO Underpricing and their Implications for IPO Research, Journal of Corporate Finance, Vol. 27, pp. 367-383.

Cornelli, F., and D. Goldreich, (2001) Bookbuilding and Strategic Allocation, Journal of Finance, Vol. 56, pp. 2337-2369.

Derrien, F., (2005) IPO Pricing in "Hot" Market Conditions: Who Leaves Money on the Table? Journal of Finance, Vol. 60, pp. 487-521.

Fan, J., K.C.J. Wei, and X. Xu, (2011) Corporate Finance and Governance in Emerging Markets: A Selective Review and Agenda for Future Research, Journal of Corporate Finance, Vol. 17, pp. 207-2014.

Habib, M. and A. Ljungqvist, (2001) Underpricing and Entrepreneurial Wealth Losses in IPOs: Theory and Evidence, Review of Financial Studies, Vol. 14, pp. 433-458.

Hanley, K.W., (1993) The Underpricing of Initial Public Offerings and the Partial Adjustment Phenomenon, Journal of Financial Economics, Vol. 34, pp. 231-250.

Hanley, K. W., and W. J. Wilhelm, (1995) Evidence on the Strategic Allocation of Initial Public Offerings, Journal of Financial Economics, Vol. 37, pp. 239-257.

Jenkinson, T. and H. Jones, (2004) Bids and Allocations in European IPO Bookbuilding, Journal of Finance, Vol. 59(5), pp.2309-2338.

Jenkinson, T. and H. Jones, (2009) IPO Pricing and Allocation: A Survey of the Views of Institutional Investors, Review of Financial Studies, Vol 22, pp. 1477-1504. 
Löffler, G., P.F. Panther and E. Theissen, (2005) Who Knows What When? The Information Content of Pre-IPO Market Prices, Journal of Financial Intermediation, Vol. 14, pp. 466-484.

Ljungqvist, A., F. Cornelli, and D. Goldreich, (2006) Investor Sentiment and Pre-IPO Markets, Journal of Finance, Vol. 61, pp. 1187-1216.

Ljungvist, A, T.J. Jenkinson, and W.J. Wilhelm, (2003) Global Integration of Primary Equity Markets: The Role of U.S. Banks and Investors, Review of Financial Studies, Vol 16, pp. 63-99.

Ljungqvist, A., V. Nanda and R. Singh, (2006) Hot Markets, Investor Sentiment, and IPO Pricing, Journal of Business, Vol. 79 (4), pp. 1667-1702.

Ljungqvist, A. and W.J. Wilhelm, (2002) IPO Allocations: Discriminatory or Discretionary? Journal of Financial Economics, Vol. 65 (2), pp. 167-201.

Loughran, T. and J.R. Ritter, (2002) Why Don't Issuers Get Upset About Leaving Money on the Table in IPOs? Review of Financial Studies, Vol. 15, pp. 413-443.

Loughran, T., J.R. Ritter, and K. Rydqvist (1994) Initial Public Offerings: International Insights, Pacific-Basin Finance Journal, Vol. 2 (2-3), pp. 165-199.

Purnanandam, A. and B. Swaminathan, (2004) Are IPOs Really Underpriced? Review of Financial Studies, Vol. 17, pp. 811-848.

Ritter, J. R., (1998) Initial Public Offerings, Contemporary Finance Digest, Vol. 2, 5-30.

Ritter, J. R.(2003) Differences between European and American IPO Markets, European Financial Management, Vol. 9(4), pp.421-434.

Ritter, J. R. and I. Welch, (2002) A Review of IPO Activity, Pricing, and Allocations, Yale ICF Working Paper No. 02-01.

Rock, K., (1986) Why New Issues are Underpriced, Journal of Financial Economics, Vol. 15, pp. 187212.

Welch, I, (1992) An Empirical Analysis of Models of Contract Choice in Initial Public Offerings, Journal of Financial and Quantitative Analysis, Vol. 26, pp. 497-518. 


\section{Appendix A. The bookbuilding process: India vs. the US}

There are fundamental differences between the bookbuilding process in India and the U.S. The biggest difference is in terms of transparency and information dispersion while the subscription orders are being received by the investment banker. In India, information of the subscriptions being received is reported live on the stock exchange website. In contrast, the book is built behind closed doors and any information on the book is almost never made public in the U.S. At best, any information is presented in a cursory manner after the book has been closed.

Bookbuilding in the U.S., Europe and some other countries has been discussed extensively in Hanley and Wilhelm (1995), Aggarwal, Prabhala and Puri (2002), Cornelli and Goldreich (2001), and Jenkinson and Jones (2004), among others. The Indian regulatory structure is very different. In India, regulations governing the bookbuilding process mandate that a fixed proportion of shares are allocated to each of the three types of investors, namely Qualified Institutional Buyers (QIBs), NonInstitutional Investors (NIIs) and Retail investors. In case of oversubscription, allocations are made by lottery within each tranche. In the post-2005 period, the investment banker does not have discretion in the allocation of shares. In sharp contrast, in the US, the lead investment bank has discretion to allocate shares to any investor they wish to. Typically, in the U.S nearly two thirds of IPO shares are allocated to institutional investors (Ljungqvist and Wilhelm 2002).

In India, the book is usually built over a period of 5 days and the maximum price of the bookbuilding range cannot be more than $120 \%$ of the lower price specified in the price range. In contrast, the length of the bookbuilding period is not mandated in the U.S. It typically follows the road-show and the difference between the minimum and maximum filed price is usually $\$ 2$ (Ritter 2003). In India the price range is almost never revised upwards in practice and is seldom revised to a lower level, if subscriber demand is unexpectedly low. Again, in sharp contrast, in US the price range may be revised several times before the filing becomes effective. Finally, for Indian IPOs the offer 
price is never set above the upper end of the price band (MAXP) whereas historically in the US, in almost $25 \%$ of offers, the offer price is set above the high end of the price range, even though the price range may have already been revised upwards (Loughran and Ritter 2002).

Finally, for IPOs in India, it takes almost 21 days before the offer is listed once the final prospectus is filed with the registrar of companies. In the US there is no delay between the offer becoming effective and its listing on NASDAQ or the Stock Exchange of choice. 
Fig1: Different stages in the Simplex Projects IPO

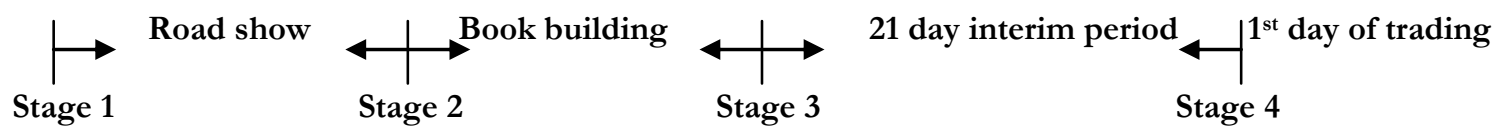

- Stage 1: The Draft Red Herring is filed without a price band.

Road Show is conducted without a price band.

- $\quad$ Stage 2: The Red Herring is filed with a price band INR 170 - 185.

Variable definition at stage $2: \mathbf{L}=170$ and $\mathbf{M A X A}=185$,

MAXP $=1.2 * 170($ lower end of the price band $\mathrm{L})=204$

Expected Voluntary Underpricing E(VUP) $=($ MAXP - MAXA $) / \mathbf{M A X P}=(204-185) / 204=9.31 \%$

The book is built using a very transparent process with the information accessible on the Bombay Stock Exchange (BSE)/National Stock Exchange websites.

- $\quad$ Stage 3: At the end of the book-building period, the Offer Price (OP) is set at INR 185 equal to MAXA.

Variable definition at stage 3:

Actual Voluntary Underpricing VUP $=(\mathbf{M A X P}-\mathbf{O P}) / \mathbf{M A X P}=(204-185) / 204=9.31 \%$

There is a 21-day interim period from the end of the book-building period until the listing of the IPO stock and its first day of trading.

- Stage 4: The first day of trading. The Closing Price (CP) at the end of the first day of trading is INR 273.70.

Variable definition at stage 4:

Initial Return $=(\mathbf{C P}-\mathbf{M A X P}) / \mathbf{M A X P}=(273.70-204) / 204=34.17 \%$

Traditional underpricing $=(\mathbf{C P}-\mathbf{O P}) / \mathbf{O P}=(273.70-185) / 185=47.95 \%$ 
Table 1: Description of the variables used in the study

\begin{tabular}{|c|c|}
\hline Variable & Description \\
\hline AGE & Number of years since incorporation of the firm to the year of the IPO \\
\hline $\mathrm{CP}$ & Closing Price(in INR*) \\
\hline IR & Initial Return $=(\mathrm{CP}-\mathrm{MAXP}) * 100 / \mathrm{MAXP}$ \\
\hline Issuesize & The amount raised in the IPO (in 00,000 INR) \\
\hline Market return & Return of the S\&P CNX Nifty, between the close of bookbuilding to the listing date \\
\hline L & Lower end of the price band actually used $[\mathrm{L}, \mathrm{MAXA}]$ in INR \\
\hline MAXA & Upper end of the price band actually used $[\mathrm{L}, \mathrm{MAXA}]$ in INR \\
\hline MAXP & Maximum permissible upper end of the price band; where MAXP $=L^{*} 1.2$, in INR \\
\hline NII_sub & $\begin{array}{l}\text { The total shares subscribed by Non-Institutional Investors (NIIs) as a proportion of the total } \\
\text { number of shares available to them for allocation. This is measured after the book has been } \\
\text { built. }\end{array}$ \\
\hline NII_Unmet & $\begin{array}{l}\text { The difference of the NII shares bid and allocated as a proportion of the total number of shares } \\
\text { offered in the IPO }\end{array}$ \\
\hline OP & Offer Price (in INR) \\
\hline Actual VUP & Actual Voluntary Underpricing $=(\mathrm{MAXP}-\mathrm{OP}) * 100 / \mathrm{MAXP}$ \\
\hline QIB_sub & $\begin{array}{l}\text { The total shares subscribed by Qualified Institutional Buyers (QIBs) as a proportion of the total } \\
\text { number of shares available to them for allocation. This is measured after the book has been } \\
\text { built. }\end{array}$ \\
\hline QIB_Unmet & $\begin{array}{l}\text { The difference of the QIB shares bid and allocated as a proportion of the total number of } \\
\text { shares offered in the IPO }\end{array}$ \\
\hline RET_sub & $\begin{array}{l}\text { The total shares subscribed by Retail Investors as a proportion of the total number of shares } \\
\text { available to them for allocation. This is measured after the book has been built. }\end{array}$ \\
\hline RET_Unmet & $\begin{array}{l}\text { The difference of the Retail shares bid and allocated as a proportion of the total number of } \\
\text { shares offered in the IPO }\end{array}$ \\
\hline NonQIB_Unmet & The sum of RET_Unmet and NII_Unmet \\
\hline Underpricing & $\begin{array}{l}\text { This is the traditional measure of market adjusted underpricing used in the literature }[(\mathrm{CP}- \\
\left.\mathrm{OP})^{*} 100 / \mathrm{OP}\right]- \text { Market return }\end{array}$ \\
\hline
\end{tabular}

*INR refers to the Indian currency, the Indian Rupee 


\section{Table 2: IPO activity and underpricing in India}

The sample includes all 362 bookbuilt issues listed on the National Stock Exchange (NSE) and the Bombay Stock Exchange (BSE), India since 2003, when regulation made it a requirement to limit the maximum permissible upper end of the price band (MAXP) to no more than $120 \%$ of the lower end pf the price band (L). The sample runs through 31 st December, 2014. The IPO size is measured by the issue proceeds measured in INR (Indian Rupee, INR approximates to 60 USD at current rates). Traditional underpricing is defined as the ratio of the excess of first day closing price to the offer price, relative to the offer price and adjusted for the market return during the period when the book has been closed but the firm has not yet listed (typically 3 weeks in the Indian context).

For the Typical IPOs (267 of the 362 offers in the sample), the offer price OP equals MAXA. For the Atypical IPOs (95 of the 362 offers) OP<MAXA, where MAXA refers to the actual maximum price set in the band [L, MAXA]. The variables are as defined in Table 1.

Panel A: Number of IPOs

\begin{tabular}{ccccc}
\hline Year & All & Typical & Atypical & \% Atypical \\
\hline 2003 & 5 & 5 & 0 & 0.00 \\
2004 & 15 & 12 & 3 & 20.00 \\
2005 & 55 & 43 & 12 & 21.82 \\
2006 & 69 & 47 & 22 & 31.88 \\
2007 & 74 & 58 & 16 & 21.62 \\
2008 & 15 & 12 & 3 & 20.00 \\
2009 & 15 & 13 & 2 & 13.33 \\
2010 & 58 & 40 & 18 & 31.03 \\
2011 & 36 & 26 & 10 & 27.78 \\
2012 & 13 & 7 & 6 & 46.15 \\
2013 & 3 & 1 & 2 & 66.67 \\
2014 & 4 & 267 & 1 & 25.00 \\
\hline
\end{tabular}


Table 2, continued

Panel B: Industrial classification of firms in the sample.

\begin{tabular}{cccc}
\hline SN & Industry & Number of Firms & As \% of the sample \\
\hline & & & \\
1 & Construction and Materials & 45 & 12.43 \\
2 & Personal Goods & 26 & 7.18 \\
3 & Software and Computer Services & 30 & 8.29 \\
4 & Media & 21 & 5.80 \\
5 & Financial Services & 25 & 6.90 \\
6 & Electricity & 21 & 5.80 \\
7 & Chemicals & 16 & 4.42 \\
8 & Industrial Engineering & 26 & 7.18 \\
9 & Real Estate Investments and Services & 16 & 4.42 \\
10 & Other & 136 & 37.58 \\
\hline \multicolumn{4}{r}{}
\end{tabular}

Panel C: Traditional underpricing of Indian book built IPOs during 2003-2014

\begin{tabular}{lcc|lll}
\hline Year & $N$ & All $(\%)$ & Typical $\%)$ & Atypical (\%) & Difference (\%) \\
\hline 2003 & 5 & 91.47 & 91.47 & - & - \\
2004 & 15 & 45.11 & 53.34 & 12.19 & 41.16 \\
2005 & 55 & 33.91 & 40.62 & 9.87 & $30.75^{*}$ \\
2006 & 69 & 18.00 & 29.11 & -5.73 & $34.84^{* * *}$ \\
2007 & 74 & 34.00 & 40.64 & 9.93 & $30.71^{* *}$ \\
2008 & 15 & 15.30 & 13.42 & 22.83 & -9.41 \\
2009 & 15 & 7.81 & 11.00 & -12.93 & 23.93 \\
2010 & 58 & 12.82 & 19.91 & -2.93 & $-22.84^{* * *}$ \\
2011 & 36 & 5.34 & 2.98 & 11.48 & -8.50 \\
2012 & 13 & 3.23 & 9.47 & -2.88 & $12.35^{*}$ \\
2013 & 3 & 3.92 & -3.62 & 7.69 & -11.31 \\
2014 & 4 & 39.35 & 47.86 & 13.85 & 34.01 \\
\hline Total & 362 & 22.79 & 29.76 & 3.20 & $26.56^{* * *}$ \\
\hline
\end{tabular}




\section{Table 3: Descriptive Statistics of the variables used in the study}

The sample is of 362 Indian IPOs. These issues are from the period where the price range was mandated by regulation to have the maximum permissible upper end of the band (MAXP) less than or equal to 120\% of the lower end of the band (L). For the Typical IPOs (267 of the 362 offers in the sample), the offer price OP equals MAXA, whereas for the Atypical offerings (95 of the 362 offers) OP $<$ MAXA, where MAXA refers to the actual maximum price set in the band $[\mathrm{L}, \mathrm{MAXA}]$. The rest of the variables are as defined in Table $1 . * * *, * * *$ indicates statistical significance at the $1 \%, 5 \%$, and $10 \%$ level, respectively.

The variables are as defined in Table 1.

\begin{tabular}{|c|c|c|c|c|c|}
\hline Variable & $N$ & All & Typical & Atypical & Difference \\
\hline Issue Size $(00,000 I N R)$ & 362 & $44,845.2$ & 39.183 .7 & $60,757.0$ & $21,573.3$ \\
\hline $\operatorname{IR}(\%)$ & 362 & 13.92 & 22.62 & -10.54 & $33.16^{* * *}$ \\
\hline Underpricing (\%) & 362 & 22.79 & 29.76 & 3.20 & $26.56^{* * *}$ \\
\hline Actual VUP (\%) & 362 & 8.25 & 6.27 & 13.79 & $-7.52 * * *$ \\
\hline $\log (A G E)$ & 360 & 2.51 & 2.54 & 2.40 & 0.14 \\
\hline RET_sub(times) & 362 & 10.63 & 13.57 & 2.37 & $11.20^{* * *}$ \\
\hline NII_sub(times) & 362 & 32.81 & 42.30 & 6.11 & $36.19^{* * *}$ \\
\hline QIB_sub(times) & 362 & 22.10 & 28.07 & 5.31 & $22.76^{* * *}$ \\
\hline RET_Unmet(ratio) & 362 & 2.95 & 3.82 & 0.49 & $3.33^{* * *}$ \\
\hline NII_Unmet(ratio) & 362 & 4.40 & 5.74 & 0.65 & $5.09 * * *$ \\
\hline QIB_Unmet(ratio) & 362 & 10.44 & 13.32 & 2.34 & $10.98^{* * *}$ \\
\hline NonQIB_Unmet(ratio) & 362 & 7.35 & 9.56 & 1.13 & $8.43^{* * *}$ \\
\hline$O P(I N R)$ & 362 & 203.23 & 193.7 & 229.9 & -36.2 \\
\hline$M A X A(I N R)$ & 362 & 208.02 & 193.7 & 248.2 & $-54.5^{* *}$ \\
\hline$M A X P(I N R)$ & 362 & 222.77 & 207.6 & 265.5 & $-57.9 * *$ \\
\hline
\end{tabular}




\section{Table 4: Likelihood of a Typical IPO}

This table examines the likelihood of the offer price OP being set equal to MAXA, where MAXA refers to the actual maximum price set in the band [L, MAXA]. The variables are as defined in Table 1.

The dependent variable takes the value of one if MAXA is equal to OP and zero otherwise. Chi-square statistics are reported in parentheses. $* * *, * * *$ indicates statistical significance at the $1 \%, 5 \%$, and $10 \%$ level, respectively.

\begin{tabular}{|c|c|c|}
\hline Independent V ariables & Coefficient & Coefficient \\
\hline (Constant) & $2.53(0.90)$ & $3.54(1.02)^{* *}$ \\
\hline NII_sub & $0.003(0.09)$ & \\
\hline RET_sub & $0.30(16.15)^{* * *}$ & \\
\hline QIB_sub & $0.09(10.09)^{* * *}$ & $0.09(12.10)^{* * *}$ \\
\hline NonQIB_sub & & $0.03(6.53)^{* *}$ \\
\hline $\log A G E$ & $0.46(3.85)^{* *}$ & $0.49(4.63)^{* *}$ \\
\hline Log_issuesize & $-0.73(15.62)^{* * *}$ & $-0.96(27.19) * * *$ \\
\hline Market_return & $0.02(0.59)$ & $0.02(0.25)$ \\
\hline $\mathrm{N}$ & 360 & 360 \\
\hline Likelihood ratio & 0.00 & 0.00 \\
\hline
\end{tabular}


Table 5: Subscription patterns of investors for different days of the bookbuilding process

This table provides the subscription patterns for 287 IPOs between April 1, 2006 and December 31st, 2014 where the day-by-day bookbuilding demand data is publicly available. Subscriptions by the three categories of investors on three different days of the bookbuilding process are presented. Panel A presents the subscription patterns on the first day of bookbuilding. Panel B presents the cumulative demands on the penultimate day of bookbuilding. Panel C presents the cumulative demand on the last day of bookbuilding. The values in Panels A-C show the subscription level, which is the ratio of the number of shares subscribed in a specific category to the number of shares on offer for that category. Thus, 1.00 indicates full subscription for that specific investor category. As per regulation, the QIB investors receive $50 \%$ of IPO shares, the NII investors receive $15 \%$ while the retail investors receive $35 \%$ of the shares.

Panel A: Investor subscription patterns on the first day of the bookbuilding process

\begin{tabular}{cccccccccc}
\hline & \multicolumn{3}{c}{ Overall } & \multicolumn{3}{c}{ Typical } & \multicolumn{3}{c}{ Atypical } \\
\hline & $\mathrm{N}$ & Mean & Median & $\mathrm{N}$ & Mean & Median & $\mathrm{N}$ & Mean & Median \\
\hline QIB & 287 & 0.89 & 0.20 & 209 & 0.96 & 0.20 & 78 & 0.69 & 0.18 \\
NII & 287 & 0.66 & 0.01 & 209 & 0.71 & 0.02 & 78 & 0.51 & 0.00 \\
Retail & 287 & 0.17 & 0.03 & 209 & 0.20 & 0.05 & 78 & 0.10 & 0.01 \\
\hline
\end{tabular}

Panel B: Investor subscription patters on the penultimate day of the bookbuilding process*

\begin{tabular}{cccccccccc}
\hline & \multicolumn{3}{c}{ Overall } & \multicolumn{3}{c}{ Typical } & \multicolumn{3}{c}{ Atypical } \\
\hline & $\mathrm{N}$ & Mean & Median & $\mathrm{N}$ & Mean & Median & $\mathrm{N}$ & Mean & Median \\
\hline QIB & 285 & 4.65 & 1.18 & 208 & 5.76 & 1.51 & 77 & 1.66 & 0.89 \\
NII & 285 & 1.66 & 0.65 & 208 & 1.92 & 0.90 & 77 & 0.98 & 0.20 \\
Retail & 287 & 1.03 & 0.45 & 209 & 1.26 & 0.54 & 78 & 0.44 & 0.13 \\
\hline
\end{tabular}

Panel C: Investor subscription patterns (cumulative) on the last day of the bookbuilding process

\begin{tabular}{lccccccccc}
\hline & \multicolumn{3}{c}{ Overall } & \multicolumn{3}{c}{ Typical } & \multicolumn{3}{c}{ Atypical } \\
\hline & $\mathrm{N}$ & Mean & Median & $\mathrm{N}$ & Mean & Median & $\mathrm{N}$ & Mean & Median \\
\hline QIB & 287 & 22.25 & 4.47 & 209 & 28.99 & 8.16 & 78 & 4.17 & 1.92 \\
NII & 287 & 31.08 & 5.22 & 209 & 40.98 & 10.91 & 78 & 4.55 & 1.71 \\
Retail & 287 & 8.80 & 3.79 & 209 & 11.36 & 6.18 & 78 & 1.94 & 1.06 \\
\hline
\end{tabular}

*For Panel B, we do not have information of the penultimate day NII and QIB subscriptions for two issues. 
Table 6: IPO Initial Returns and subscription quartiles:

This table provides the initial returns (IR) by subscription quartiles for 362 Indian IPOs. IR is defined as the excess of first day closing price (CP) over MAXP, relative to MAXP. MAXP is the maximum permissible upper end of the price band. For the Typical Offerings the offer price OP equals MAXA whereas for the Atypical Offerings OP $<$ MAXA, where MAXA refers to the actual maximum price set in the band [L, MAXA]. The rest of the variables are as defined in Table 1. The table presents the subscription by quartiles of the three categories of investors. As per regulation, $50 \%$ of IPO shares are allocated to QIB investors, the NII investors receive $15 \%$ while the retail investors receive $35 \%$ of the shares. Panel A presents the initial returns, IR, by subscription level quartiles for all 362 observations, while Panels B and $\mathrm{C}$ show the initial returns by subscription level quartiles for Typical and Atypical IPOs, respectively.

Panel A: First day initial returns (IR) by subscription quartiles $(\mathrm{N}=362)$

\begin{tabular}{ccccc}
\hline & First Quartile & Second Quartile & Third Quartile & Fourth Quartile \\
\hline QIB & -6.69 & -1.74 & 17.97 & 46.26 \\
NII & -7.04 & -6.92 & 16.83 & 53.00 \\
Retail & -10.49 & 0.58 & 13.23 & 52.64 \\
\hline
\end{tabular}

Panel B: First day initial returns (IR) by subscription quartiles Typical IPOs (N=267)

\begin{tabular}{ccccc}
\hline & First Quartile & Second Quartile & Third Quartile & Fourth Quartile \\
\hline \multirow{2}{*}{ QIB } & -2.80 & 9.64 & 23.12 & 46.50 \\
NII & 1.01 & -4.81 & 20.63 & 53.91 \\
Retail & -2.83 & 2.58 & 14.60 & 54.41 \\
\hline
\end{tabular}

Panel C: First day initial returns (IR) by subscription quartiles Atypical IPOs (N=95)

\begin{tabular}{ccccc}
\hline & First Quartile & Second Quartile & Third Quartile & Fourth Quartile \\
\hline QIB & -14.88 & -13.89 & 0.79 & 24.85 \\
NII & -14.74 & -10.80 & -4.05 & 26.52 \\
Retail & -14.07 & -5.63 & -1.03 & 1.13 \\
\hline
\end{tabular}




\section{Table 7: The determinants of Initial Returns (NII, Retail, and QIB Investors)}

The dependent variable in each of the regressions is Initial Return (IR). Two observations of the original 362 are excluded due to missing data. Thus, the regression analysis uses 360 observations. For the Typical Offerings (267 of the 360 offers), the offer price OP equals MAXA whereas for the Atypical Offerings (93 of the 360 offers) OP $<$ MAXA, where MAXA refers to the actual maximum price set in the band [L, MAXA]. The rest of the variables are as defined in Table 1. T-statistics are reported in parentheses.

$I R=\beta_{0}+\beta_{1}\left(\mathrm{NII} \_\right.$sub $)+\beta_{2}\left(\mathrm{RET} T_{-}\right.$sub $)+\beta_{3}\left(\mathrm{QIB} \_\right.$sub $)+\beta_{4}\left(\log \_A G E\right)+\beta_{5}\left(\log\right.$ issuesize $\left._{2}\right)+\beta_{6}($ Market_return $)+\beta_{7}($ Actual VUP $)+$ year dummies $+\varepsilon$

\begin{tabular}{cccc} 
& All & Typical Offers & Atypical Offers \\
\hline Independent Variables & Coefficient & Coefficient & Coefficient \\
$(1)$ & $11.53(0.42)$ & $15.13(0.42)$ & $75.95(1.52)$ \\
\hline Constant) & $0.26(3.95)^{* * *}$ & $0.29(3.99)^{* * *}$ & $0.19(0.57)$ \\
NII_sub & $0.88(4.38)^{* * *}$ & $0.77(3.38)^{* * *}$ & $-1.20(-0.68)$ \\
RET_sub & $0.07(0.85)$ & $0.09(0.92)$ & $0.78(1.45)$ \\
QIB_Sub & & & \\
Log_AGE & $0.52(0.20)$ & $3.24(0.98)$ & $-5.21(-1.21)$ \\
Log_issuesize & & & $-3.39(-1.14)$ \\
Market_return & $-3.28(-1.81)^{*}$ & $-5.58(-2.20)^{* *}$ & $1.28(2.04)^{* *}$ \\
Actual VUP & $1.56(4.58)^{* * *}$ & $1.59(3.83)^{* * *}$ & \\
$\mathrm{~N}$ & $-1.17(-3.04)^{* * *}$ & $-1.36(-2.02)^{* *}$ & $-1.44(-2.20)^{* *}$ \\
Adj. R-square & 360 & 267 & 93 \\
\hline & $46.66 \%$ & $44.54 \%$ & $10.27 \%$ \\
\hline
\end{tabular}

*** indicates significance at $1 \%$ level

$* *$ indicates significance at $5 \%$ level

$*$ indicates significance at $10 \%$ level 


\section{Table 8: The determinants of Initial Returns (Combining NII and Retail Investors)}

The dependent variable in each of the regressions is Initial Return (IR). Two observations of the original 362 are excluded due to missing data. Thus, the regression analysis uses 360 observations. For the Typical Offerings (267 of the 360 offers), the offer price OP equals MAXA whereas for the Atypical Offerings (93 of the 360 offers) OP $<$ MAXA, where MAXA refers to the actual maximum price set in the band [L, MAXA]. The rest of the variables are as defined in Table 1. T-statistics are reported in parentheses.

$I R=\beta_{0}+\beta_{1}\left(N o n Q I B \_s u b\right)+\beta_{2}\left(Q I B \_s u b\right)+\beta_{3}\left(\log \_\right.$AGE $)+\beta_{4}\left(\log \_i s s u e s i z e\right)+\beta_{5}($ Market_return $)+\beta_{6}($ Actual VUP $)+$ year dummies $+\varepsilon$

(2)

\begin{tabular}{cccc} 
& All & Typical offers & Atypical Offers \\
\hline Independent Variables & Coefficient & Coefficient & Coefficient \\
\hline Constant) & $99.61(4.15)^{* * *}$ & $116.74(4.00)^{* * *}$ & $59.19(1.34)$ \\
NonQIB_sub & $0.39(8.99)^{* * *}$ & $0.40(8.26)^{* * *}$ & $0.05(0.19)$ \\
QIB_Sub & $0.07(0.86)$ & $0.10(0.96)$ & $0.68(1.32)$ \\
Log_AGE & $1.32(0.52)$ & $4.22(1.28)$ & $-4.55(-1.08)$ \\
Log_issuesize & $-4.71(-2.71)^{* * *}$ & $-7.08(-2.98)^{* * *}$ & $-2.87(-1.00)$ \\
Market_return & $1.49(4.37)^{* * *}$ & $1.52(3.68)^{* * *}$ & $1.35(2.18)^{* *}$ \\
Actual VUP & $-1.15(-2.98)^{* * *}$ & $-1.37(2.02)^{* *}$ & $-1.36(-2.12)^{* *}$ \\
$\mathrm{~N}$ & 360 & 267 & 93 \\
Adj. R-square & $45.83 \%$ & $44.14 \%$ & $10.84 \%$ \\
\hline
\end{tabular}

*** indicates significance at $1 \%$ level

$* *$ indicates significance at $5 \%$ level

$*$ indicates significance at $10 \%$ level 


\section{Table 9: The determinants of Initial Returns using the unmet demand for QIB and Non-QIB investors}

The dependent variable in each of the regressions is Initial Return (IR). Two observations of the original 362 are excluded due to missing data. Thus, the regression analysis uses 360 observations. For the Typical Offerings (267 of the 360 offers), the offer price OP equals MAXA whereas for the Atypical Offerings (93 of the 360 offers) OP $<$ MAXA, where MAXA refers to the actual maximum price set in the band [L, MAXA]. The rest of the variables are as defined in Table 1. T-statistics are reported in parentheses.

\begin{tabular}{|c|c|c|c|}
\hline & All & Typical offers & Atypical Offers \\
\hline Independent Variables & Coefficient & Coefficient & Coefficient \\
\hline (Constant) & $79.07(3.24)^{* * *}$ & $92.51(3.09)^{* * *}$ & $60.12(1.31)$ \\
\hline NonQIB_Unmet & $2.09(9.68)^{* * *}$ & $2.10(8.71)^{* * *}$ & $-0.21(-0.11)$ \\
\hline QIB_Unmet & $0.22(1.43)$ & $0.27(1.48)$ & $0.83(0.88)$ \\
\hline $\log A G E$ & $0.02(0.01)$ & $2.22(0.67)$ & $-4.88(-1.14)$ \\
\hline Log_issuesize & $-3.21(-1.83)^{*}$ & $-5.06(-2.09)^{* *}$ & $-1.98(-0.70)$ \\
\hline Market_return & $1.47(4.31)^{* * *}$ & $1.49(3.58)^{* * *}$ & $1.42(2.28)^{* *}$ \\
\hline Actual VUP & $-1.27(-3.29)^{* * *}$ & $-1.34(-1.96)^{*}$ & $-1.54(-2.43)^{* *}$ \\
\hline$N$ & 360 & 267 & 93 \\
\hline Adj. R-square & $45.75 \%$ & $43.48 \%$ & $8.98 \%$ \\
\hline
\end{tabular}

*** indicates significance at $1 \%$ level

** indicates significance at 5\% level

$*$ indicates significance at $10 \%$ level 


\section{Table 10: The effect of regulatory regime shift on the determinants of Initial Returns}

In India, the underwriter's discretionary allocation powers were removed in November, 2005. Two observations of the original 362 are excluded due to missing data. Thus, the regression analysis uses 360 observations. For the Typical Offerings (267 of the 360 offers), the offer price OP equals MAXA whereas for the Atypical Offerings (93 of the 360 offers) OP $<$ MAXA, where MAXA refers to the actual maximum price set in the band [L, MAXA]. The variable Period equals one for IPOs following the removal of the underwriters' discretionary allocation powers, and is set at zero otherwise. All other variables are as defined in Table 1.

$$
\begin{aligned}
& \left.I R=\beta_{0}+\beta_{1}(\text { Period })+\beta_{2}(\text { NonQIB_Unmet })+\beta_{3}(\text { NonQIB_Unmet_Period })+\beta_{4}\left(Q I B \_U n m e t\right)+\beta_{5}(\text { QIB_Unmet_Period })+\beta_{6} L \text { Log AGE }\right)+ \\
& \beta_{7}(\log \text { issuesize })+\beta_{8}(\text { Market_return })+\beta_{9}(\text { Actual VUP })+\text { year dummies }+\varepsilon
\end{aligned}
$$

\begin{tabular}{|c|c|c|c|}
\hline & All & Typical offers & Atypical Offers \\
\hline Independent V ariables & Coefficient & Coefficient & Coefficient \\
\hline (Constant) & $36.86(2.06)^{* *}$ & $49.39(2.15)^{* *}$ & $44.82(1.45)$ \\
\hline Period & $8.16(1.08)$ & $10.39(1.09)$ & $-6.56(-0.49)$ \\
\hline NonQIB_Unmet & $2.781(8.07)^{* * *}$ & $2.75(7.07)^{* * *}$ & $-1.13(-0.36)$ \\
\hline NonQIB_Unmet_Period & $-1.09(-2.66)^{* * *}$ & $-1.04(-2.28)^{* *}$ & $1.80(0.45)$ \\
\hline QIB_Unmet & $0.40(0.87)$ & $0.63(1.23)$ & $0.44(0.24)$ \\
\hline QIB_Unmet_Period & $-0.05(-0.10)$ & $-0.22(-0.43)$ & $0.27(0.12)$ \\
\hline Log_AGE & $-1.35(-0.54)$ & $0.58(0.18)$ & $-4.52(-1.11)$ \\
\hline Log_issuesize & $-3.42(-2.07)^{* *}$ & $-5.37(-2.40)^{* *}$ & $-2.02(-0.83)$ \\
\hline Market_return & $1.43(4.44)^{* * *}$ & $1.50(3.86)^{* * *}$ & $1.13(1.98)^{*}$ \\
\hline Actual VUP & $-1.56(-4.27)^{* * *}$ & $-1.96(-3.37)^{* * *}$ & $-1.41(-2.25)^{* *}$ \\
\hline$N$ & 360 & 267 & 93 \\
\hline Adj. R-square & $46.24 \%$ & $44.11 \%$ & $10.24 \%$ \\
\hline
\end{tabular}

*** indicates significance at $1 \%$ level

** indicates significance at $5 \%$ level

* indicates significance at $10 \%$ level 